\title{
Correction to: Application of smart mosquito monitoring traps for the mosquito forecast systems by Seoul Metropolitan city
}

Sumi Na and Hoonbok Yi ${ }^{*}$

\section{Correction to: J Ecol Environ (2020) 44:13 \\ https://doi.org/10.1186/s41610-020-00155-w}

Following publication of the original article (Na and $\mathrm{Yi}$ 2020), the authors would like to replace the current acknowledgement with the following:

This work was supported by a research grant from Seoul Women's University (2020-0084).

Published online: 07 December 2020

\section{Reference}

$\mathrm{Na} \mathrm{S}, \mathrm{Yi} \mathrm{H}$. Application of smart mosquito monitoring traps for the mosquito

forecast systems by Seoul Metropolitan city. J Ecol Environ. 2020;44:13

https://doi.org/10.1186/s41610-020-00155-w.

* Correspondence: yih@swu.ac.kr

Department of Bio \& Environmental Technology, Graduate School of Seoul Women's University, Seoul, South Korea

(C) The Author(s). 2020 Open Access This article is licensed under a Creative Commons Attribution 4.0 International License, which permits use, sharing, adaptation, distribution and reproduction in any medium or format, as long as you give appropriate credit to the original author(s) and the source, provide a link to the Creative Commons licence, and indicate if changes were made. The images or other third party material in this article are included in the article's Creative Commons licence, unless indicated otherwise in a credit line to the material. If material is not included in the article's Creative Commons licence and your intended use is not permitted by statutory regulation or exceeds the permitted use, you will need to obtain permission directly from the copyright holder. To view a copy of this licence, visit http://creativecommons.org/licenses/by/4.0/. 